Check for updates

Montreal

Cite this as: BMJ 2021;374:n2353

http://dx.doi.org/10.1136/bmj.n2353

Published: 23 September 2021

\section{Covid-19: Rich countries' booster plans will impede global vaccination, experts say}

\author{
Owen Dyer
}

A summit convened alongside the UN's annual meeting in New York, bringing 80 governments together to discuss the global response to the covid-19 pandemic, is expected to end with a collective endorsement of the US president's call for $70 \%$ of people in countries of all income levels to be vaccinated by the time the UN General Assembly meets again 12 months from now.

But this goal will not be met, experts warned, unless rich countries change course now, releasing the stocks they are currently hoarding.

Shortly after Joe Biden spoke, the US Food and Drug Administration gave the green light for third dose booster shots of the Pfizer-BioNTech vaccine for Americans who face a high risk of exposure and people aged over 65 . The UK, meanwhile, expects to administer about 30 million boosters this winter. The World Health Organization has pleaded with rich countries not to go ahead with booster shots, arguing that the need for first doses in poorer countries was far more pressing.

"We can do both, and it's a false choice," argued White House spokeswoman Jen Psaki. The US will buy an extra 500 million doses of the Pfizer vaccine to donate to low and low-middle income countries, Biden announced this week, bringing the total US pledge to 1.1 billion doses. "Put another way, for every one shot we have administered to date in America, we have now committed to do three shots to the rest of the world," he said.

About six billion doses are needed to vaccinate low and low-middle income countries, the same as the total number of doses administered worldwide so far.

The US, Biden said, aims to become the "arsenal of vaccines, as we were the arsenal of democracy during World War II.” It will be "donating, not selling” vaccines, he noted, in a veiled criticism of China and Russia, who have generally charged for their products.

But the White House acknowledged that fewer than 300 million of these 1.1 billion doses will be donated by the end of the year.

The pledge to vaccinate $70 \%$ of people in countries of all income levels is the first clear global target to be embraced by national governments, but it also represents a retreat from the goal set by the UN, WHO, and World Bank to vaccinate $40 \%$ of people in low and low-middle income countries by the end of 2021 and $70 \%$ by mid-2022. There is now no chance of even approaching the target for 2021.

To date, fewer than $2 \%$ of people in low income countries have received a single dose, a fraction of the $54 \%$ in high income countries. The gap has only grown in recent months.

"High income countries have promised to donate more than one billion doses, but less than $15 \%$ of those doses have materialised," WHO director general Tedros Adhanom Ghebreyesus said earlier this month. "We don't want any more promises, we just want the vaccines.”

UN secretary general Antonio Guterres this week called global vaccine inequity an "obscenity" and gave the world an "F in ethics" for its response. The pandemic has seen the world veer badly off course for meeting sustainable development goals set by the international community in 2015, the UN reported this week. ${ }^{2}$

“Today's summit was full of speeches but tragically lacking in action," said Oxfam America's president, Abby Maxman. The extra 500 million doses were welcome, she said, but "still a drop in the bucket compared to the urgent need across the world."

\section{Patent restrictions}

Maxman said, "President Biden and leaders of rich countries should listen to what leaders from developing countries are asking for: the rights and the recipe to make their own vaccine doses.

"In their remarks to the summit, the leaders of South Africa and India highlighted a proposal by more than 100 countries at the WTO to waive intellectual property restrictions so that those countries can produce their own vaccines for their own citizens. But almost none of the rich country leaders today addressed that proposal, including President Biden.”

Biden endorsed such a waiver in May, but the US government has put no pressure on companies or allies to follow suit.

Russia has sponsored the creation of 34 sites abroad to manufacture the Sputnik vaccine, but while these worked well for the first doses they have struggled to produce the different viral vector used in the second Sputnik dose. A group of Indian and international organisations last week sent an open letter to Biden urging him to let these facilities use the formula for the similar Johnson and Johnson vaccine, which they are well suited to produce. ${ }^{3}$

The world is on course to produce enough vaccines next year to theoretically cover everybody, Moderna chief executive Stéphane Bancel told the Swiss newspaper Neue Zuercher Zeitung on 23 September. "If you look at the industry-wide expansion of production capacities over the past six months, enough doses should be available by the middle of next year so that everyone on this earth can be 
vaccinated. Boosters should also be possible to the extent required," he said.

Bancel predicted that, one way or another, widespread immunity will have largely suppressed the pandemic by next September. "Those who do not get vaccinated will immunise themselves naturally," he said, "because the delta variant is so contagious."

1 Wise J. Covid-19: Booster doses to be offered to 30 million people in UK. BMJ2021;374:n2261 doi: 10.1136/bmj.n2261 pmid: 34521637

2 Gennari P. Tracking progress on food and agriculture-related SDG indicators 2021. Sep 2021 http://www.fao.org/sdg-progress-report/2021/en.

3 Indian Civil Society letter to Johnson \& Johnson and the Government of the United States. 16 Sep 2021. https://accessibsa.org/indian-civil-society-letter-jj.

This article is made freely available for use in accordance with BMJ's website terms and conditions for the duration of the covid-19 pandemic or until otherwise determined by BMJ. You may use, download and print the article for any lawful, non-commercial purpose (including text and data mining) provided that all copyright notices and trade marks are retained. 